\title{
GSE Activity, FHA Feedback, and Implications for the Efficacy of the Affordable Housing Goals ${ }^{1}$
}

\author{
Xudong An \\ Raphael W. Bostic \\ School of Policy, Planning, and Development \\ Lusk Center for Real Estate \\ University of Southern California
}

February 13, 2006

\footnotetext{
${ }^{1}$ Contact information: (1) An, xudongan@usc.edu, 213-821-1351, 213- 740-0373 (fax); (2) Bostic, bostic@usc.edu, 213-740-1220, 213-740-6170 (fax). The authors are grateful for helpful comments from Yongheng Deng, Robert Dunsky, James Follain, George Galster, Cheng Hsiao, Juliet Musso, Frank Nothaft, Wayne Passmore, and participants at 2006 Annual AREUEA meetings in Boston and the $46^{\text {th }}$ ACSP annual conference in Kansas City. We thank the USC Lusk Center for Real Estate for financial support.
} 


\title{
GSE Activity, FHA Feedback, and Implications for the Efficacy of the Affordable Housing Goals
}

\begin{abstract}
There is a seeming paradox about the "affordable housing goals": GSE activities in targeted communities have increased under the goals but there has been little measurable improvement in housing market conditions in these communities. This paper seeks to reconcile this paradox by focusing on linkage between GSE purchases and FHA activities. We build a simple model based on credit rationing theory that suggests that GSE activities can have a feedback effect on FHA. More aggressive GSE pursuit of targeted borrowers under the affordable housing goals induces potential FHA borrowers with best credit quality to use the conventional market. In response, the FHA applies more strict underwriting standards under new market equilibrium, which results in reduced loan volumes. On balance, these effects can offset and make credit supply and homeownership effectively unchanged. Empirical evidence on changes in GSE and FHA lending after affordable housing goals were made more binding is found to be consistent with the theoretical predictions.
\end{abstract}

\section{Keywords}

Affordable housing goals, GSE, FHA, homeownership, underserved neighborhoods, credit rationing 


\section{GSE Activity, FHA Feedback, and Implications for the Efficacy of the Affordable Housing Goals}

\section{Introduction}

In order to facilitate credit access and homeownership among lower-income and minority households, the Federal Housing Enterprise Financial Safety and Soundness Act of 1992 (GSE Act) empowered the U. S. Department of Housing and Urban Development (HUD) to establish targets for Fannie Mae and Freddie Mac (together, the GSEs) purchases of mortgages originated to members of these groups. These "affordable housing goals" have led the GSEs to increase their service to the targeted groups (see, for example, Listokin and Wyly, 2000). However, evidence has tended to not show a direct impact of the goals and GSE purchase activities on credit access and homeownership (Ambrose and Thibodeau, 2004; Bostic and Gabriel, 2004). Thus, there is a seeming paradox: GSE activities in targeted communities have increased but there has been little measurable improvement in the access to credit and housing market conditions in these communities.

This paper seeks to reconcile this paradox. Its focus is on the linkage between GSE purchases and activities of the Federal Housing Administration (FHA), which also plays a key role regarding homeownership attainment of lower-income and minority households through its insurance program.

We build a simple model based on credit rationing theory which shows that GSE activities can have a feedback effect on FHA: more aggressive GSE pursuit of targeted borrowers under the affordable housing goals induces potential FHA borrowers with best credit quality to use the conventional market and obtain conforming conventional loans instead. In response, the FHA applies more strict underwriting standards under new market equilibrium, which results in reduced loan volumes. On balance, these effects offset and make credit supply and homeownership effectively unchanged. 
We test this model by establishing whether intensified GSE purchases are associated with a reduction in FHA activities in targeted neighborhoods and find that such a relationship exists, in support of the theory. In so doing, we explore how FHA responds to the changing market environment brought by the goals, and seek some explanation of the seeming paradox.

The study makes several contributions. Its focus allows for new insights regarding the relationships between different segments of the mortgage market and how these relationships change as the institutional setting evolves. Second, its findings can inform ongoing policy debates, including whether the thresholds for the affordable housing goals are appropriate, and whether new incentives should be provided for the GSEs to help expand homeownership opportunity for underserved populations.

The next section briefly reviews the policy context and existing studies related to the current research. Section 3 develops a simple theoretical model based on credit rationing theory. Sections 4 and 5 describe the empirical approach and data and report the empirical results. Concluding remarks are in a final section.

\section{Policy context and existing literature}

Homeownership among lower-income and minority populations in the United States persistently lags that for the population at large. For example, the overall homeownership rate in 2003 was 68.3 percent, but only 51.8 percent for lower-income families and about 45 percent for minorities (U. S. Department of Housing and Urban Development, 2005b).

These gaps have drawn the attention of policy makers, and were a major impetus for the passage of the GSE Act and the establishment of the affordable housing goals. Policy makers believed passage would impart particular benefits provided by the GSEs, 
including lower borrower mortgage costs and increased competition and credit flow, to lower-income and minority communities. ${ }^{2}$

The affordable housing goals require the GSEs to have a certain proportion of their purchases be of mortgages made to lower-income borrowers (the "low and moderate income" goal), borrowers residing in lower-income communities and borrowers in certain high minority neighborhoods (the "underserved neighborhoods" goal), and borrowers with low and very low incomes that live in low income areas (the "special affordable" goal). ${ }^{3}$ HUD is charged with specifying GSE purchase percentage requirements for each category and adjusting the percentage periodically, as market conditions shift. HUD established the first set of affordable housing goals in 1995 and these have evolved over time. Appendix A documents their evolution.

A sizable literature has emerged which examines the success of the GSEs in meeting the affordable housing goal thresholds. This research has found that the GSEs have responded positively to the affordable housing goals. For example, Bunce and Scheessele (1996), Bunce (2002) and Manchester (1998) show that the GSEs increased the proportion of their loan purchases to targeted populations in the years following the enactment of the GSE Act. In addition, Listokin and Wyly (2000) and Temkin, et al. (2001) show that the GSEs enhanced their product offerings so as to facilitate more purchases of loans from targeted communities. These new products often featured underwriting criteria that depart from industry norms and allow for higher risks. A recent government assessment of GSE performance regarding the affordable goals concluded

\footnotetext{
${ }^{2}$ Hendershott and Shilling (1989), Cotterman and Pearce (1996), Ambrose, Buttimer and Thibodeau (2001), ICF (1990), U.S. Congressional Budget Office (2001), Naranjo and Toevs (2002), Passmore, Sparks and Ingpen (2002) and Ambrose, LaCoure-Little and Sanders (2004), among many others, have shown that GSE activities are related to substantial mortgage rate reductions. See McKenzie (2002) and Sanders (2005) for surveys of the literature. González-Rivera (2000) and Roll (2003) argue that homeowners benefit not only from GSEs' guarantees, but also from their portfolio investments. Harrison, et al. (2002) shows that GSEs can help lower-income and minority communities by reducing information externalities and increasing transactions in thin markets.

${ }^{3}$ The GSE Act defines lower-income borrowers as having incomes less than the area median income. It defines lower-income neighborhoods as those with a median income less than 90 percent of the area median income and high minority neighborhoods as those with a minority population share that is at least 30 percent and a median income less than 120 percent of the area median. Low and very low income borrowers are defined by the Act those with incomes less than 80 percent and 60 percent of the area median income, respectively.
} 
that the GSEs had generally fulfilled their goal requirements (U.S. Department of Housing and Urban Development, 2005a).

This research has also found that the GSEs have not played a leading role in serving lower-income and minority populations. For example, Bunce and Scheessele (1996) find that the "shares of the GSEs' business going to lower income borrowers and underserved neighborhoods typically fall short of the corresponding shares of other market participants"(page 3). Other researchers, including Manchester, et al. (1998) and Case, et al. (2002) reach similar conclusions.

While these studies focused on GSE activities directly, another set of studies has focused on market outcomes associated with the increased GSE purchases in response to the affordable housing goals. Freeman and Galster (2004) examine underserved neighborhoods in Cleveland between 1993 and 1999 to see if GSE activity is associated with changes in single-family home sales volumes and prices. They find no links between secondary market activities, by the GSEs or others, and sales prices. In addition, while they do find some evidence indicating that secondary market activities are associated with some increases in sales volumes, their analysis suggests that GSE purchase activities do not drive this relationship.

Bostic and Gabriel (2004) empirically evaluates changes in the homeownership rate, vacancy rate, and median house value among GSE-targeted census tracts relative to changes in a control group of similar tracts. They find limited direct effects of affordable housing goal incentives on local housing market outcomes in California during the 1990s. Ambrose and Thibodeau (2004) analyze another dimension of market outcomes - the credit supply. After building a credit supply-demand system and estimating their model based on historical data on mortgage lending and economic and demographic variables, they conclude that the affordable housing goals had a limited effect on the overall supply of mortgage credit to targeted groups in the largest 308 metropolitan statistical areas during 1995 and 1999. 
Therefore the existing studies suggest a paradox. On one hand, GSEs increased their purchase activities to targeted groups under the affordable housing goals, which should result in increased access to credit and improved housing market outcomes. On the other hand, the evidence suggests that these positive market outcomes did not occur.

This research argues that market dynamics between GSE activities and those of the FHA might help to explain the seemingly paradoxical findings. Created under the National Housing Act of 1934, FHA provides mortgage insurance mainly to those borrowers who do not have sufficient down payment or have higher debt-to-income ratios. Loans with FHA insurance are originated using more flexible underwriting standards than those originated in the conventional market. For example, the FHA program allows the borrower to have a payment-to-income ratio as high as 36 percent as opposed to the 28 percent threshold used for conventional loans. Similarly, under the FHA program, borrowers can have a downpayment that is less then 5 percent of the home's value, whereas institutions offering private mortgage insurance generally do not insure mortgages with loan-to-value ratios above 95 percent. FHA loans are therefore generally more costly than conventional loans (Gabriel and Rosenthal, 1991; Hendershott, Lafayette and Haurin, 1997; Ambrose, Pennington-Cross and Yezer, 2002). Nonetheless, research indicates that conventional and FHA loan products compete for many borrowers, particularly those with marginal credit quality (Ambrose, et al., 2002; Bradford, 2002; Nothaft and Trentcheva, 2003; Abt, 2004).

Given that GSEs generally do not purchase FHA loans, our intuition is that intensified GSE purchases targeting underserved populations under the affordable housing goals have a feedback effect on FHA. More aggressive GSE pursuit of targeted borrowers under the affordable housing goals induces potential FHA borrowers with the best credit quality to use the conventional market and obtain conforming conventional loans instead. In response, the FHA has to apply more strict underwriting standards to keep its risk profile within an acceptable level and consequently reduces its loan volume. This feedback effect offsets the increase in credit supply associated with the GSE purchases and limits changes in housing market outcomes. 
There are a few empirical studies which analyze the dynamic relationship between FHA and conventional lending (or private mortgage insurance, PMI). For example, Ambrose, Pennington-Cross and Yezer (2002) find that, as economic uncertainty increases, FHA market share increases and conventional market share decreases. Nothaft and Trentcheva (2003) find that the FHA loan limit increase both expands the lending market and "crowds" out some conventional activity. However, the market dynamics in these studies are not formally modeled as is done below.

\section{Theoretical model: credit rationing and market dynamics}

This section formalizes the intuition outlined above by presenting a model of FHA behavior that justifies the FHA imposition of stricter underwriting standards in response to intensified GSE purchases. The model modifies the credit rationing theories pioneered by Stiglitz and Weiss (1981) by tailoring it to the mortgage market. In the model, mortgage lenders will approve only some of the loan applications they receive, and will reject those that do not meet their underwriting standards. There are mainly two types of lenders, conventional and FHA, and conventional lenders have stricter underwriting criteria. Thus, a higher risk borrower that does not qualify for a conventional loan can gain credit in FHA market, provided his risk level does not exceed FHA risk tolerances.

Following Ferguson and Peters (1995), Ambrose, Pennington-Cross and Yezer (2002), and Gan and Riddiough (2003), we assume that all relevant information concerning the applicant's quality for a mortgage, including credit history, collateral quality, and loan terms, can be uniquely summarized by a single "mortgage credit score", $\theta, \theta \in(0,1]$, in which the probability of default is $1-\theta$. Denote $1-\theta$ as $\Phi$, so that $\Phi$ is a monotonically increasing measure of credit risk. Each lender sets uniform underwriting standards such that all applicants with a credit risk above a threshold (maximum risk tolerance level), $\Phi^{*}$ are rejected, while all applicants with a credit risk below $\Phi^{*}$ are accepted. Denote the density function of $\Phi$ as $f(\Phi)$. For the whole application pool, it measures the number of applicants at risk $\Phi$. Then 


$$
\int_{0}^{1} f(\Phi) d \Phi=1
$$

is the normalized application pool over time. For simplicity, we assume $f(\Phi)$ does not change over time. ${ }^{4}$

Consider a simple two period model. Let $t_{1}$ be a date before the implementation of affordable housing goals and $t_{2}$ be a date after goals implementation. Also, let the thresholds for the maximum risk tolerance levels for conventional and FHA loans at $t_{1}$ be defined as $\Phi^{C}$ and $\Phi^{F}$ respectively, $0<\Phi^{C}<\Phi^{F}<1$. Taking the whole application pool as unity, the number of mortgage borrowers in the conventional and FHA market are given respectively by:

$$
C\left(\Phi^{C}\right)=\int_{0}^{\Phi^{C}} f(\Phi) d \Phi
$$

and

$$
F\left(\Phi^{C}, \Phi^{F}\right)=\int_{\Phi^{C}}^{\Phi^{F}} f(\Phi) d \Phi
$$

Further assume that the FHA charges a risk premium $P_{f}$ for each borrower insured, and suffers a loss of $L(\Phi)$ in case of borrower default. We assume that $P_{f}$ remains constant over $\left[t_{1}, t_{2}\right]$ and that $L^{\prime}(\Phi) \geq 0 .^{5}$

Under competitive markets, the economic profits for the FHA should be zero. Therefore,

$$
G\left(\Phi^{C}, \Phi^{F}\right)=P_{f} \int_{\Phi^{C}}^{\Phi^{F}} f(\Phi) d \Phi-\int_{\Phi^{C}}^{\Phi^{F}} \Phi L(\Phi) f(\Phi) d \Phi=0
$$

Assume that at time $t_{2}$, the market changes due to GSE pursuit of loans to targeted groups to meet the affordable housing goals. By relaxing their purchase underwriting criteria, the GSE provide the best credit among the pool of borrowers that the FHA previously served

\footnotetext{
${ }^{4}$ This assumption is not critical. Further, the empirical results remain unchanged when this assumption is relaxed.

${ }^{5}$ FHA insurance premium did change in 1983 and 2001, but did not change between 1996 and 2000, which is the study period.
} 
with a choice between the FHA and conventional loan products. These relatively high quality borrowers will opt for the conventional conforming loans because FHA loans are generally more costly. Therefore, risk threshold dividing the conventional and GHA markets shifts to $\Phi^{C^{\prime}}$, with $\Phi^{C^{\prime}}>\Phi^{C}$.

Let the threshold for FHA loans in time $t_{2}$ be denoted as $\Phi^{F}$ '. Then, the new conventional and FHA lending markets can be described as:

$$
\bar{C}\left(\Phi^{C}\right)=\int_{0}^{\Phi^{C^{\prime}}} f(\Phi) d \Phi
$$

and

$$
\bar{F}\left(\Phi^{C}, \Phi^{F}\right)=\int_{\Phi^{C}}^{\Phi^{F^{\prime}}} f(\Phi) d \Phi
$$

Since economic profits for the FHA must still be zero, the new FHA market equilibrium must satisfy

$$
\bar{G}\left(\Phi^{C^{\prime}}, \Phi^{F^{\prime}}\right)=P_{f} \int_{\Phi^{C^{\prime}}}^{\Phi^{F^{\prime}}} f(\Phi) d \Phi-\int_{\Phi^{C^{\prime}}}^{\Phi^{F^{\prime \prime}}} \Phi L(\Phi) f(\Phi) d \Phi=0
$$

It is straightforward to prove that for (7) to hold, we must have $\Phi^{F}{ }^{\prime}<\Phi^{F}$, which means that FHA must decrease its maximum risk tolerance (apply more strict underwriting standards). We summarize the above arguments in the following proposition.

Proposition 1: When GSEs respond to affordable housing goals by more aggressively pursuing purchases in targeted areas through an easing of underwriting standards $\left(\Phi^{C^{\prime}}>\right.$ $\left.\Phi^{C}\right)$, the FHA, in order to preserve its portfolio risk profile, must apply more strict underwriting standards $\left(\Phi^{F^{\prime}<\Phi^{F}}\right)$.

Proof: We can rewrite $G\left(\Phi^{C}, \Phi^{F}\right)$ in equation (4) as

$$
\begin{aligned}
& G\left(\Phi^{C}, \Phi^{F}\right)=\int_{\Phi^{C}}^{\Phi^{F}}\left(P_{f}-\Phi L(\Phi)\right) f(\Phi) d \Phi \\
& \text { Defining } g(\Phi, L(\Phi))=P_{f}-\Phi L(\Phi), \frac{\partial g(\Phi, L(\Phi))}{\partial \Phi}=-L(\Phi)-\Phi L^{\prime}(\Phi)<0 \quad \forall \Phi
\end{aligned}
$$


Thus, $g(\Phi, L(\Phi))$ is a monotonically decreasing function of $\Phi$.

Therefore, for $G(a, b)=\int_{a}^{b} g(\Phi, L(\Phi)) f(\Phi) d \Phi=0$, we must have $g(a, L(a)>0$, $g(b, L(b)<0$ and there exist a unique $c, a<c<b \quad$ s.t. $\quad g(c, L(c)=0$.

And we can rewrite $G(a, b)=\int_{a}^{c} g(\Phi, L(\Phi)) f(\Phi) d \Phi+\int_{c}^{b} g(\Phi, L(\Phi)) f(\Phi) d \Phi=0$

Now it's readily that for $a^{\prime}>a$ and $G\left(a^{\prime}, b^{\prime}\right)=\int_{a^{\prime}}^{c} g(\Phi, L(\Phi)) f(\Phi) d \Phi+\int_{c}^{b^{\prime}} g(\Phi, L(\Phi)) f(\Phi) d \Phi=0$, we must have $b^{\prime}<b$.

Therefore, for $\bar{G}\left(\Phi^{C^{\prime}}, \Phi^{F^{\prime}}\right)=P_{f} \int_{\Phi^{C^{\prime}}}^{\Phi^{F^{\prime}}} f(\Phi) d \Phi-\int_{\Phi^{C^{\prime}}}^{\Phi^{F^{\prime}}} \Phi L(\Phi) f(\Phi) d \Phi=0$ and $\Phi^{C^{\prime}}>\Phi^{C}$, we must have $\Phi^{F}<\Phi^{F}$.

Figures 1 and 2 depict the market dynamics between $t_{1}$ and $t_{2}$. Figure 1 shows the distribution of the mortgage applicants at date $t_{1}$. Conventional market applicants fall in area I, FHA market applications are in area II, and those that will be rejected or fall in the subprime market are in area III.

Figure 2 shows the new market composition at date $t_{2}$. The FHA loses its best quality borrowers, those from the lower end of its risk profile, and it raises its underwriting standards to exclude some borrowers from the higher end of the risk profile under the new equilibrium.

Thus, one important implication of the above model is that even if the GSEs are making efforts to meet the affordable housing goals, the overall market credit supply and homeownership for low and minorities might not change significantly, or could even decline.

Of course $\Phi^{\mathrm{F}}$ need not adjust if the FHA was to increase its insurance premiums or it was willing to insure a portfolio with greater expected losses. In either case, the economic profit condition could be satisfied without necessarily requiring a shift in the underwriting threshold. Consistent with this latter possibility, the FHA did experience 
significant losses in the 1980s and 1990s (Hendershott and Waddell, 1992). However, the FHA did not change its insurance premium during our study period, which might suggest that a shifting of $\Phi^{\mathrm{F}}$ was more likely over this time (Capone, 2002).

While many mortgage lenders, particularly those serving non-prime mortgage markets, use a risk-based pricing approach whereby a borrower loan rates are directly tied to individual levels of creditworthiness, the FHA uses a different approach. The FHA charges the same premium to all borrowers that are covered under its Mutual Mortgage Insurance Program, which is the equivalent of using an average pricing scheme. It is important to note that the key aspects of the model pertain to the fact that there is differential underwriting such that the mortgage market is partitioned between a market serving high-quality borrowers and a market that serves lower-quality borrowers. As long as such a partition occurs, and lower-quality applicants can not get a mortgage in the higher-quality market, then the model's results hold independent of the pricing scheme used by FHA and other lenders.

\section{Empirical approach}

The remainder of the paper empirically tests the theoretical model. If the model is correct, the GSE market share in targeted areas should increase after the implementation of the goals and this increase should cause the market share of FHA to shrink. We test for this relationship in two ways. First, we examine national trends between 1996 and 2000 in the GSE and FHA market shares of lending among census tracts grouped by income. The theory predicts one should observe increasing GSE and decreasing FHA shares in tracts targeted by the affordable housing goals. Second, to more accurately characterize the relationship between GSE and FHA activities, we control for other factors which might contribute to changes in their market shares by estimating

$$
\Delta F_{i}=\alpha+\eta \Delta G_{i}+\gamma \Delta G_{i} I_{i}+\beta Z_{i}+\varepsilon_{i}
$$

Here, $\Delta F_{i}$ is the change of market share of FHA between $t_{1}$ and $t_{2}$ in census tract $i ; \Delta G_{i}$ is the change of GSE market share during the same period; $I_{i}$ is an indicator of GSE targeted tracts; and $Z_{i}$ is a set of control variables that includes the change in proportion 
of FHA eligible loans, the change in economic environment, and a set of demographic and economic variables thought to influence housing and lending decisions. The theoretical model implies negative values for $\eta$ and $\gamma$.

To be sure that observed market share changes are the result of the GSE activities under the affordable housing goals, it is necessary to establish a counterfactual of local housing market activity in the absence of increased GSE loan purchases under the goals. Tracts with median incomes below 90 percent of the area median are targeted under the underserved neighborhoods goal of the affordable housing goals (see footnote 5). Following the approach for establishing a counterfactual introduced in Avery, Calem, and Canner (2003), we restrict our sample to those census tracts with median incomes between 80 and 100 percent of the area median income. We use 80 percent as the lower bound because the Community Reinvestment Act (CRA) requires the banks to help lower-income borrowers defined as having family income as less than 80 percent of tract median and we want to distinguish the GSE effect from CRA effect.

Within this restricted sample, tracts with median incomes between 80 and 90 percent of the area median are our treatment group and tracts having median incomes between 90 and 100 percent of the area median are the control group. The control group is thus as close as possible to the treatment group to minimize the likelihood that a tract in the treatment group is too different from those in the control group. The empirical test thus compares how GSE and FHA market shares evolve in targeted and non-targeted tracts. In addition to the hypothesis that changes in GSE market share are negatively related to changes in FHA market share, we hypothesize that market share differences should expand more in targeted tracts than in non-targeted tracts.

We note that this is an indirect test, as the theoretical model focuses on risk thresholds and changes in underwriting standards for conventional and FHA lending. Unfortunately, data on these variables are not widely available to permit a direct test of how they evolve over time. 


\section{Data and empirical results}

\subsection{Data sources}

The empirical analysis uses data pursuant to Home Mortgage Disclosure Act (HMDA) as its primary data source. ${ }^{6}$ HMDA provides the most comprehensive mortgage-related dataset in terms of coverage. It contains loan level mortgage application and origination information, including borrowers' demographic traits, like age, race and income, loan type, loan amount, location of property, origination status and certain institutional variables all over the nation. Information on neighborhood demographic and economic characteristics are drawn from the 1990 and 2000 Census. Metropolitan statistical area (MSA) data on regional income, employment, and wages are taken from the U.S. Bureau of Labor Statistics.

The analysis is restricted to owner-occupied home purchase loans. Loans originated by lenders specializing in the subprime market or in manufactured housing as identified by HUD are excluded. ${ }^{7}$ We use published information on FHA and conforming loan limits to identify FHA-eligible and conventional conforming loans. Following Bunce (1996), we exclude loans with loan-to-income or loan amount outliers. ${ }^{8}$ The loan-level HMDA data are aggregated at the tract level, focusing on census tracts in metropolitan areas.

The analysis focuses on two years, 1996 and 2000. We choose 1996 because it falls before the affordable housing goal thresholds increased (see Appendix A). Thus, it serves as a "pre-treatment" observation. The year 2000 was chosen because it falls within the treatment period after the goals had increased substantially and had a similar interest rate environment to that observed in 1996 (see Appendix B). Lending in 2000 thus reflects the GSE response to the increased goal requirements and FHA responses to market conditions, including the GSE response.

\footnotetext{
${ }^{6}$ HMDA, enacted by Congress in 1975 and implemented by the Federal Reserve Board's Regulation C, requires lending institutions to report public loan data, mainly to enforce fair lending.

${ }^{7}$ HUD monitors lenders annually and develops a list of institutions that engage significantly in subprime lending. While this list has acknowledged shortcomings, it is the best available source for identifying subprime loans during the analytical period. For more on this list, see http://www.huduser.org/datasets/manu.html.

${ }^{8}$ See table 1 for a detailed description of the criteria used to exclude loans.
} 
The sample contains 43,970 census tracts with about 2.7 million home purchase loan originations in 1996 and 44,196 tracts with nearly 3.3 million originations in 2000.

\subsection{Empirical results}

Tables 1 and 2 report sample statistics. Loan volumes have increased markedly since 1996 (table 1). Between 1996 and 2000, for example, loan volumes increased by 21.8 percent. Most loan originations involved conventional loans, with FHA loans making up about 21 percent of total loan volume on average. In a given year, between 25 and 35 percent of all originated loans are sold to a GSE. Among FHA-eligible loans (those loans whose size does not exceed the FHA loan limit), a slightly smaller percentage is conventional although comparable proportions are sold to the GSEs.

Table 2 reports on our two years of focus, 1996 and 2000, and presents the data in terms of GSE and FHA market shares. The data show that, in moving from 1996 to 2000, consistent with the theoretical model, the GSE share grew while the FHA share contracted in every tract income category. The most significant share gains for GSEs and share losses for the FHA occur among tracts that fall under the affordable housing goals. Moreover, FHA market share losses were negligible among higher income tracts that presumably are not the focus of the affordable housing goals. These relationships, also presented graphically in Figure 3, are broadly consistent with the predictions of the theoretical model developed above.

Turning to the multivariate tests, recall that this set of analysis was conducted using a sample restricted only to those census tracts with median incomes between 80 and 100 percent of the area median so as to have a reasonable control group. While the tracts in the control group are similar to those in the treatment group, they are not identical (table 3). Control group tracts tend to have better housing market characteristics and different demographic and economic characteristics. Consistent with findings from prior research, GSE activity is proportionately stronger in control group tracts than in targeted affordable 
housing goal tracts. These facts serve to emphasize the importance of including multivariate controls.

The multivariate results, reported in table 4 , confirm the observed findings from tables 1 and 2 suggesting that FHA feedback is important. Estimation using a very parsimonious specification (model 1) indicates that an increase in the GSE market share in a tract is associated with a decrease in the FHA market share in that tract. It is important to emphasize that this relationship is not pre-ordained - the combined GSE and FHA share was approximately 50 percent, so the GSE gain could have come at the expense of other market participants. An FHA share reduction in this context is therefore significant. Contrary to expectations, however, we do not find the FHA feedback effect to be stronger in tracts targeted by the affordable goals (interactive term in table 4). This lack of a targeted effect might be due to the fact that the GSEs establish rules for purchasing loans that are applied to all tracts, and not just to those targeted by the affordable goals. The same result indicating an FHA feedback response is also found using the more comprehensive empirical specification of equation 8 (model 2).

The other lending-related relationships conform to expectations. FHA market share increases with the prevalence of FHA-eligible loans. It decreases with overall loan volume, which is consistent with the GSE effect described by the theory but also could reflect rapid growth in lending to non-FHA populations. Finally, FHA market shares increase with increases in a census tract's average loan-to-income ratio, which is a crude measure of borrower risk. This result is consistent with the FHA's role in serving households posing greater default risk.

Because overall lending could include many loans that the FHA could not purchase because they exceed the FHA loan size threshold, a more focused and perhaps more appropriate test would involve repeating the analysis and restricting the sample to include only FHA-eligible loans. This is done in the final two columns of table 4. Here again, the results strongly suggest an FHA feedback response to GSE purchase activities, both in the short and more comprehensive specifications. A second finding, that the FHA 
market share falls as the number of FHA-eligible loans increases, also supports the notion that the FHA is being out-competed for loans it could potentially service. This result holds controlling for the change in the GSE market share, which argues for the importance of non-GSE activity in these areas.

A related question is whether the feedback effect is stronger under some housing market conditions than under others. Affordability could be a particularly important dimension, as financing is likely to be much more important in areas with low affordability. In such markets, the FHA could be a more important player and the feedback effect could thus be more significant. Results, shown in table 5, indicate that while the FHA feedback effect does tend to be stronger in markets with lower affordability, the difference is not statistically significant.

\section{Conclusions and Discussions}

It has been over ten years since the implementation of the affordable housing goals, which were designed to increase GSE presence in transactions involving lower-income and minority populations in order to improve access to credit and homeownership. However, the empirical evidence suggests a puzzle. On one hand, substantial evidence shows that the GSEs have responded positively to the affordable housing goals by allocating more of their purchases to the targeted groups defined by the goals. On the other hand, recent research finds limited improvement for these neighborhoods in terms of credit supply, home sale volumes and prices, homeownership, and other housing market outcomes.

This paper tries to reconcile the seeming paradox by focusing on the linkage between GSE purchases and FHA activities. We build a simple theoretical model based on credit rationing theory which shows that GSE activities can have a feedback effect on the FHA. More aggressive GSE pursuit of targeted borrowers under the affordable housing goals induces potential FHA borrowers with best credit quality to use the conventional market and obtain cheaper conforming conventional loans instead of FHA loans. In response to the loss of its best credits, in order to maintain the risk profile of its portfolio so as to 
avoid losses, the FHA applies more strict underwriting standards under a new market equilibrium, which results in reduced loan volumes. On balance, these effects work in opposite directions and can leave credit supply and homeownership unchanged or possibly even reduced.

Our empirical analysis of changes of market shares of FHA and GSE supports the theoretical hypothesis of a feedback loop between GSE purchases and FHA activities. There is a significant negative relationship between the change in GSE and FHA market shares, which is consistent with the view that more aggressive GSE purchases in "underserved neighborhoods" result in a significant retreat of FHA activities. This relationship is not pre-ordained, as the combined GSE and FHA share was approximately 50 percent. The GSE gain could have come at the expense of other market participants.

There is an ongoing debate regarding whether HUD should continue to raise the affordable housing goals thresholds, with some in opposition arguing that this might have a negative impact on primary market participants such as the FHA (for example, National Association of Realtors, 2004, Independent Community Bankers of America, 2004). Both our theoretical and empirical results on the dynamic between GSE purchases and FHA activities suggest there may be some merit to this view. However, one must note that FHA loans are generally higher cost than conventional conforming loans, and so there is considerable benefit for those households able to switch from an FHA loan to a conventional loan as a result of affordable housing goal incentives. A full benefit-cost analysis has yet to be completed and remains for future researchers.

There are other issues for future researchers to examine. Our test of the theoretical model relied on an indirect measure of the feedback effect. Additional effort in trying to develop more direct tests of our hypothesis could yield more definitive answers. For example, if data permitted, we could estimate a default risk model, simulate default risks of FHA loans, and then compare the risk distribution of the FHA portfolios before and after the establishment of the affordable housing goals and the subsequent GSE response. While there are limited possibilities for this during the time period we analyze, new data 
sources might arise that will be useful in this regard. Alternatively, recent data available through HMDA on mortgage pricing might be useful in tracking changes in average prices for GSE-purchased and FHA-insured loans. Such changes might be indicative of changes in the risk profiles of the respective portfolios. Further, the current analysis is static in nature. An analysis based on a panel data set may yield new insights into the market dynamics between GSE and FHA activities.

In conclusion, regardless of the outcome of the various debates about the affordable housing goals policy, one thing is clear. Homeownership is important. Given this fact, policy-makers should continue searching for new instruments to help lower-income and minority households gain access to credit and homeownership. 


\section{References}

Abt Associates Inc. 2004. The GSEs in the Low-income Market. Report to the US Department of Housing and Urban Development. September 17, 2004.

Ambrose, B. W., R. Buttimer and T. G. Thibodeau. 2001. A New Spin on the Jumbo/Conforming Loan Rate Differential. Journal of Real Estate Finance and Economics, 23(3): 309-335.

Ambrose, B. W., M. LaCour-Little and A. B. Sanders. 2004. The Effect of Conforming Loan Status on Mortgage Yield Spreads: A Loan Level Analysis. Real Estate Economics, 32(4): 541-569.

Ambrose B. W., A. Pennington-Cross and A. M. Yezer. 2002. Credit Rationing in the US Mortgage Market: Evidence Based on Variations in FHA Market Shares. Journal of Urban Economics, 51(2): 272-294.

Ambrose, B. W. and T. G. Thibodeau. 2004. Have the GSE Affordable Housing Goals Increased the Supply of Mortgage Credit? Regional Science and Urban Economics, 34(3): 263-273.

Avery, Robert B., Paul S. Calem and Glenn B. Canner. 2003. The Effects of the Community Reinvestment Act on Local Communities. Proceedings of Federal Reserve System conference.

Bester, H. 1985. Screening versus Rationing in Credit Markets with Imperfect Information. American Economic Review, 75(4): 850-855.

Bostic, R.W. and S. A. Gabriel. 2004. Do the GSEs Matter to Low-income Housing Markets? University of Southern California, Lusk Center for Real Estate working paper, 2005-1001.

Bradford, C. 2002. The Patterns of GSE Participation in Minority and Racially Changing Markets Reviewed from the Context of the Levels of Distress Associated with High Levels of FHA Lending. Cityscape, 6(1): 145-214.

Bunce, H. L. 2002. The GSEs' Funding of Affordable Loans: A 2000 Update. U.S. Department of Housing and Urban Development, Housing Finance Working Paper Series HF-013.

Bunce, H. L., and R. M. Scheessele. 1996. The GSEs' Funding of Affordable Loans. US Department of Housing and Urban Development, Research report, No. HF-001.

Canner, G. B, S. A. Gabriel and J. M. Woolley. 1991. Race, Default Risk, and Mortgage Lending: A Study of the FHA and Conventional Loan Markets. Southern Economic Journal, 58(1): 249-162.

Capone, C. A. Jr. 2002. Credit Risk, Capital, and Federal Housing Administration Mortgage Insurance. Journal of Housing Research, 11(2): 373-401.

Case, B., K. Gillen and S. M. Wachter. 2002. Spatial Variation in GSE Mortgage Purchase Activity. Cityscape, 6(1): 9-84.

Cotterman, R. F. and J. E. Pearce. 1996. The Effects of the Federal National Mortgage Association and the Federal Home Loan Mortgage Corporation on Conventional Fixed-Rate Mortgage Yields, in Studies on Privatizing Fannie Mae and Freddie Mac. Washington, D.C.: U.S. Department of Housing and Urban Development. May 1996.

Ferguson, M. F. and S. R. Peters. 1995. What Constitutes Evidence of Lending Discrimination? Journal of Finance, 50(2): 739-748. 
Freeman, L. and G. Galster. 2004. The Impact of Secondary Mortgage Market and GSE Purchases on Underserved Neighborhood Housing Markets: A Cleveland Case Study, working paper.

Gabriel, S. A. and S, Rosenthal. 1991. Credit Rationing, Race, and the Mortgage Market. Journal of Urban Economics, 29(3): 371-379.

Gan, J. and T. J. Riddiough. 2003. Piercing and then Papering over the Vail of Ignorance: GSE Monopoly and Informational Advantage in the Market for Residential Mortgages. Working paper presented at the 2004 Annual American Finance Association (AFA) Meetings, San Diego.

González-Rivera, G. 2000. Liquidity Function and Transference Function in the Market for Mortgages: The Role of Retained Portfolio Investments. University of California, Riverside, Department of Economics working paper. September 2000.

Goodman, J. L. Jr., and J. B. Nichols. 1997. Does FHA Increase Homeownership or Just Accelerate It? Journal of Housing Economics, 6(2): 184-202.

Harrison, D., W. Archer, D. Ling and M. Smith. 2002. Mitigating Information Externalities in Mortgage Markets: The Role of Government-Sponsored Enterprises. Cityscape, 6(1): 115143.

Hendershott, P. H., W. C. Lafayette and D. R. Haurin. 1997. Debt Usage and Mortgage Choice: The FHA-Conventional Decision. Journal of Urban Economics, 41(2): 202-217.

Hendershott, P. H. and J. D. Shilling. 1989. The Impact of the Agencies on Conventional FixedRate Mortgage Yields. Journal of Real Estate Finance and Economics, 2(1): 1-15.

Hendershott, P. H. and J. A. Waddell. 1992. The Changing Fortunes of FHA's Mutual Mortgage Insurance Fund and the Legislative Procedure. Journal of Real Estate Finance and Economics, 5(2): 119-132.

ICF Inc. 1990. Effects of the Conforming Loan Limit on Mortgage Markets. Report prepared for the U.S. Department of Housing and Urban Development.

Independent Community Bankers of America. 2004. Letters to Regulators: Housing Goals for Fannie Mae and Freddie Mac, to the US Department of Housing and Urban Development. July 16, 2004.

http://www.icba.org/advocacy/commentlettersdetail.cfm?ItemNumber=677\&sn.ItemNumber $=1711$

Listokin, D. L., and E. K. Wyly. 2000. Making New Mortgage Markets: Case Studies of Institutions, Home Buyers, and Communities. Housing Policy Debate, 11(3): 575-644.

McKenzie, J. A. 2002. A Reconsideration of the Jumbo/Non-Jumbo Mortgage Rate Differential. Journal of Real Estate Finance and Economics, 25(2/3): 197-214.

Manchester, P. B. 1998. Characteristics of Mortgages Purchased by Fannie Mae and Freddie Mac, 1996-97 Update. U.S. Department of Housing and Urban Development, Housing Finance Working Paper Series HF-006.

Naranjo, A. and A. Toevs. 2002. The Effects of Purchases of Mortgages and Securitization by Government Sponsored Enterprises on Mortgage Yield Spreads and Volatility. Journal of Real Estate Finance and Economics, 25(2/3): 173-196.

National Association of Realtors. 2004. Re: Proposed Housing Goals for Fannie Mae and Freddie Mac for 2005-2008, Docket No. FR-4790-P-01. July 15, 2004. http://www.realtor.org/gapublic.nsf/pages/gsegoalslet?OpenDocument. 
Nothaft, F. E., and P. T. Trentcheva. 2003. Does FHA "Crowd-Out" Private Mortgage Insurance? Working paper presented at the 2003 Annual American Real Estate and Urban Economics Association (AREUEA) Meetings, Washington, DC.

Passmore, W., R. Sparks and J. Ingpen. 2002. GSEs, Mortgage Rates, and the Long-Run Effects of Mortgage Securitization. Journal of Real Estate Finance and Economics, 25(2/3): 215-243.

Roll, R. 2003. Benefits to Homeowners from Mortgage Portfolios Retained by Fannie Mae and Freddie Mac. Journal of Financial Services Research, 23(1): 29-42.

Sanders, A. B. 2005. Measuring the Benefits of Fannie Mae and Freddie Mac to Consumers: Between De Minimis and Small? The Ohio State University working paper, July 2005.

Stiglitz, J. E. and A. Weiss. 1981. Credit Rationing in Markets with Imperfect Information. American Economic Review, 71(3): 393-410.

Temkin, K., R. Quercia, and G. Galster. 2001. The Impact of Secondary Mortgage Market Guidelines on Affordable and Fair Lending: A Reconnaissance from the Front Lines. Review of Black Political Economy, 28(2): 29-52.

U.S. Congressional Budget Office. 2001. Interest Rate Differentials between Jumbo and Conforming Mortgages. A CBO Paper. May 2001.

U.S. Department of Housing and Urban Development. 2005a. "Overview of the GSEs'Housing Goal Performance, 1996-2003." http://www.huduser.org/datasets/gse.html.

U.S. Department of Housing and Urban Development. 2005b. Annual performance plan. 
Table 1: Composition and geographic coverage of the sample from HMDA, 19962002

\begin{tabular}{lccccccc}
\hline \hline & 1996 & 1997 & 1998 & 1999 & 2000 & 2001 & 2002 \\
\hline & & & & & & & \\
Number of tracts & 43,970 & 43,901 & 43,931 & 44,005 & 44,196 & 44,191 & 46,857 \\
& & & & & & & \\
All loans & & & & & & & \\
Total originations (000s) & 2,699 & 2,710 & 3,148 & 3,315 & 3,287 & 3,443 & 3,474 \\
Type of loan (percent) & & & & & & & \\
$\quad$ Conventional & 72.13 & 71.08 & 73.31 & 72.82 & 74.56 & 74.71 & 78.38 \\
FHA & 21.09 & 22.65 & 20.47 & 21.86 & 20.95 & 20.73 & 17.77 \\
VA & 6.40 & 5.85 & 5.77 & 4.98 & 4.25 & 4.31 & 3.64 \\
$\quad$ Other & 0.38 & 0.42 & 0.45 & 0.34 & 0.24 & 0.25 & 0.21 \\
Purchase type & & & & & & & \\
$\quad$ Not sold & 35.57 & 30.36 & 25.15 & 29.14 & 28.15 & 28.15 & 25.34 \\
FNMA & 14.68 & 15.28 & 19.12 & 16.23 & 16.74 & 17.14 & 20.45 \\
$\quad$ FHLMC & 11.51 & 10.60 & 13.09 & 11.60 & 11.65 & 13.14 & 13.15 \\
$\quad$ Other & 38.24 & 43.76 & 42.64 & 43.03 & 43.46 & 41.57 & 41.06 \\
& & & & & & & \\
FHA-eligible loans & & & & & & & \\
Total originations (000s) & 1,786 & 1,879 & 2,195 & 2,373 & 2,336 & 2,471 & 2,475 \\
Type of loan (percent) & & & & & & & \\
Conventional & 63.98 & 62.56 & 65.59 & 65.32 & 67.36 & 67.86 & 72.36 \\
FHA & 29.14 & 30.88 & 27.85 & 28.97 & 27.72 & 27.29 & 23.79 \\
Sold to GSE & 24.29 & 24.15 & 30.05 & 26.54 & 27.34 & 28.00 & 32.28 \\
\hline
\end{tabular}

NOTE: The sample covers tracts from all income range, not only those with 80 to 100 percent of MSA median family income. Following Bunce (1996), we use several filters on the HMDA data to get our sample here: 1) The sample contains only loans originated for home purchase.

Refinance, home improvement and multifamily loans are excluded; 2) We only focus on MSAs, thus loans made in non-MSAs are excluded; 3) Only loans for owner-occupied properties are included; 4) Subprime/manufactured loans are excluded. We identify them with HUD's subprime/manufactured lender list; 5) We exclude those with very small loan amount (less than $\$ 15,000$, suspect to be home improvement loans) and those with very high loan to income ratio (greater than 6, suspect to have misreport on income). For the geographic coverage, we exclude in 2002 two states which have one tract and two tracts, respectively. Panel A includes all home purchase loans originated with above filters; while Panel B shows FHA eligible loans. FHA eligible loans are identified by comparing the loan amount with published FHA loan limit in each year for each county. 
Table 2: GSE and FHA market shares by tract, overall and by relative median income, 1996 and 2000

\begin{tabular}{|c|c|c|c|c|c|c|}
\hline & \multicolumn{3}{|c|}{ GSE } & \multicolumn{3}{|c|}{ FHA } \\
\hline & 1996 & 2000 & Change & 1996 & 2000 & Change \\
\hline \multicolumn{7}{|l|}{ All loans } \\
\hline All tracts & 26.31 & 28.55 & $+8.53 \%$ & 20.91 & 20.55 & $-1.70 \%$ \\
\hline \multicolumn{7}{|l|}{ Tract relative median income } \\
\hline Less than 80 percent & 19.10 & 21.60 & $+13.08 \%$ & 35.25 & 34.31 & $-2.65 \%$ \\
\hline $80-90$ percent & 21.87 & 25.07 & $+14.63 \%$ & 28.97 & 28.05 & $-3.20 \%$ \\
\hline 90-100 percent & 24.37 & 27.42 & $+12.50 \%$ & 25.69 & 25.18 & $-1.96 \%$ \\
\hline $100-120$ percent & 27.33 & 29.71 & $+8.68 \%$ & 21.46 & 21.45 & $-0.04 \%$ \\
\hline 120 percent or more & 29.52 & 31.15 & $+5.52 \%$ & 12.51 & 12.32 & $-1.58 \%$ \\
\hline Total number of loans (000s) & 704 & 930 & & 560 & 669 & \\
\hline \multicolumn{7}{|l|}{ FHA-eligible loans } \\
\hline All tracts & 24.30 & 27.51 & $+13.18 \%$ & 29.18 & 27.51 & $-5.71 \%$ \\
\hline \multicolumn{7}{|l|}{ Tract relative median income } \\
\hline Less than 80 percent & 18.09 & 20.83 & $+15.16 \%$ & 38.07 & 36.29 & $-4.68 \%$ \\
\hline $80-90$ percent & 20.62 & 24.01 & $+16.44 \%$ & 32.77 & 30.23 & $-7.75 \%$ \\
\hline 90-100 percent & 22.72 & 26.31 & $+15.81 \%$ & 30.70 & 29.30 & $-4.55 \%$ \\
\hline $100-120$ percent & 25.47 & 28.51 & $+11.93 \%$ & 28.13 & 27.94 & $-0.68 \%$ \\
\hline 120 percent or more & 29.06 & 31.72 & $+9.18 \%$ & 22.92 & 22.23 & $-3.00 \%$ \\
\hline Total number of loans $(000 \mathrm{~s})$ & 433 & 636 & & 520 & 636 & \\
\hline
\end{tabular}

Note: All numbers except those indicated are in percentage. GSE and FHA market shares are calculated as number of GSE purchases or FHA insured loans divided by total number of loan originations in specific income group and in specific year. Relative median income for a census tract is calculated as the tract's median household income divided by the median household income for the metropolitan area in which the tract is located. 
Table 3: Comparison of census tract housing, demographic and economic variables among different income groups

\begin{tabular}{|c|c|c|c|}
\hline & $\begin{array}{c}\text { Marginal } \\
\text { tracts }(80- \\
100 \%)\end{array}$ & $\begin{array}{c}\text { Tracts above } \\
\text { margin }(90- \\
100 \%)\end{array}$ & $\begin{array}{c}\text { Tracts below } \\
\text { margin (80- } \\
90 \%)\end{array}$ \\
\hline \multicolumn{4}{|l|}{ Housing market indicators } \\
\hline Homeownership rate, 1990 & 57.11 & 58.60 & $55.57 * * *$ \\
\hline Homeownership rate, 2000 & 57.56 & 59.21 & $55.88 * * *$ \\
\hline Change in homeownership rate, $1990 \mathrm{~s}$ & 1.21 & 1.48 & $0.93 * *$ \\
\hline Vacancy rate, 1990 & 7.72 & 7.39 & $8.05^{* * *}$ \\
\hline Change in vacancy rate, $1990 \mathrm{~s}$ & 6.33 & 4.79 & $7.91 * *$ \\
\hline Median house value, 1990 & 87885.16 & 92760.86 & $82899.79 * * *$ \\
\hline Change in median house value, $1990 \mathrm{~s}$ & 41.99 & 41.57 & 42.42 \\
\hline \multicolumn{4}{|l|}{ Demographic characteristics } \\
\hline Percentage aged 17 or less, 1990 & 24.26 & 24.01 & $24.51 * * *$ \\
\hline Percentage aged 65 or older, 1990 & 14.11 & 13.98 & 14.23 \\
\hline Percentage minority, 1990 & 20.73 & 18.39 & $23.13 * * *$ \\
\hline Percentage Asian, 1990 & 3.25 & 3.24 & 3.27 \\
\hline Unemployment rate, $1990(\%)$ & 4.31 & 3.95 & $4.68 * * *$ \\
\hline Household size, 1990 & 2.64 & 2.64 & 2.65 \\
\hline Percentage central city tracts & 45.26 & 42.68 & $47.89 * * *$ \\
\hline Percentage 1-4 unit structures, 1990 & 84.27 & 84.29 & 84.24 \\
\hline Percentage single family homes, 1990 & 67.39 & 69.45 & $65.28 * * *$ \\
\hline Number of owner-occupied units, 1990 & 1014.30 & 1055.97 & $971.69 * * *$ \\
\hline Change in number of units, $1990 \mathrm{~s}$ & 9.92 & 10.97 & $8.84 * * *$ \\
\hline Change in median family income, $1990 \mathrm{~s}$ & 38.99 & 38.96 & 39.01 \\
\hline \multicolumn{4}{|l|}{ Metropolitan area characteristics } \\
\hline Per capita income in PMSA, 1990 & 19020.26 & 19002.06 & 19038.87 \\
\hline Share of Population Employed, 1990 (\%) & 0.49 & 0.49 & 0.49 \\
\hline Per capita wages in PMSA, 1990 & 22266.66 & 22254.33 & 22279.26 \\
\hline Change in PMSA per capita income, $1990 \mathrm{~s}$ & 51.43 & 51.36 & 51.49 \\
\hline Change in PMSA employment, 1990s & 4.38 & 4.34 & 4.43 \\
\hline Change in PMSA per capita wages, 1990 & 47.18 & 47.18 & 47.18 \\
\hline \multicolumn{4}{|l|}{ GSE purchase intensity } \\
\hline Share of loans purchased by GSEs, $1995-2000$ & 0.2357 & 0.2498 & $0.2212 * * *$ \\
\hline Share of loans purchased by GSEs, 1995 & 0.2473 & 0.2601 & $0.2340 * * *$ \\
\hline Share of loans purchased by GSEs, 2000 & 0.2439 & 0.2540 & $0.2335 * * *$ \\
\hline Number of tracts & 8003 & 4046 & 3957 \\
\hline
\end{tabular}

NOTE: We exclude tracts with too low $(<15 \%)$ or too high $(>80 \%)$ homeownership rates Tracts with less than one hundred 1 to 4 unit housing structures, or with missing values on MSA economic variables are also excluded. We end up with a sample of 27132 census tracts from all income range. Column 1 shows the sample tracts with median family income as $80-100 \%$ of MSA median. Columns 2 and 3 are tracts with $90-100 \%$ and $80-90 \%$ of MSA median family income respectively. All change variables are in percent. The numbers in the table are means. We use both means and variances to test the difference of group mean, which is labeled by asterisks in column 3. An asterisk (*) indicates a value that is statistically different from the above margin sample (column 3 ); $* * *-p<.001, * *-p$ $<.01, *-\mathrm{p}<.05$. 
Table 4: Regression results for percent change of FHA market share, 1996-2000

\begin{tabular}{|c|c|c|c|c|}
\hline & \multicolumn{2}{|c|}{ All loans } & \multicolumn{2}{|c|}{ FHA-eligible loans } \\
\hline & Model 1 & Model 2 & Model 3 & Model 4 \\
\hline Intercept & $\begin{array}{c}0.00 \\
(0.01)\end{array}$ & $\begin{array}{l}0.04^{*} \\
(0.02)\end{array}$ & $\begin{array}{c}0.00 \\
(0.01)\end{array}$ & $\begin{array}{c}0.05 * * \\
(0.02)\end{array}$ \\
\hline Percent change in GSE market share & $\begin{array}{c}-0.08 * * * \\
(0.02)\end{array}$ & $\begin{array}{c}-0.11 * * * \\
(0.02)\end{array}$ & $\begin{array}{c}-0.09 * * * \\
(0.02)\end{array}$ & $\begin{array}{c}-0.12 * * * \\
(0.02)\end{array}$ \\
\hline GSE target * Percent change in GSE market share & $\begin{array}{c}0.01 \\
(0.02)\end{array}$ & $\begin{array}{c}0.02 \\
(0.02)\end{array}$ & $\begin{array}{c}0.02 \\
(0.02)\end{array}$ & $\begin{array}{c}0.03 \\
(0.02)\end{array}$ \\
\hline Percent change in proportion of FHA-eligible loans & $\begin{array}{c}0.15^{* * *} \\
(0.01)\end{array}$ & $\begin{array}{c}0.15^{* * *} \\
(0.01)\end{array}$ & & \\
\hline Percent change in total number of loan originations & $\begin{array}{c}-0.23 * * * \\
(0.02)\end{array}$ & $\begin{array}{c}-0.14 * * * \\
(0.02)\end{array}$ & & \\
\hline Percent change in number FHA-eligible loans & & & $\begin{array}{c}-0.17 * * * \\
(0.02)\end{array}$ & $\begin{array}{c}-0.08 * * * \\
(0.02)\end{array}$ \\
\hline Percent change in average loan-to-income ratio & & $\begin{array}{c}0.05^{* * *} \\
(0.01)\end{array}$ & & $\begin{array}{c}0.10 * * * \\
(0.01)\end{array}$ \\
\hline Percentage aged 17 or less, 1990 & & $\begin{array}{l}0.04 * \\
(0.02)\end{array}$ & & $\begin{array}{c}0.04 \\
(0.02)\end{array}$ \\
\hline Percentage aged 65 or older, 1990 & & $\begin{array}{c}0.07 * * * \\
(0.02)\end{array}$ & & $\begin{array}{c}0.06^{* * * *} \\
(0.02)\end{array}$ \\
\hline Percentage minority, 1990 & & $\begin{array}{l}-0.03 \\
(0.02)\end{array}$ & & $\begin{array}{l}-0.04^{*} \\
(0.02)\end{array}$ \\
\hline Percentage Asian, 1990 & & $\begin{array}{c}0.01 \\
(0.02)\end{array}$ & & $\begin{array}{l}0.05 * * \\
(0.02)\end{array}$ \\
\hline Unemployment rate, $1990(\%)$ & & $\begin{array}{c}0.08 * * * \\
(0.01)\end{array}$ & & $\begin{array}{c}0.08 * * * \\
(0.01)\end{array}$ \\
\hline Household size, 1990 & & $\begin{array}{c}0.02 \\
(0.02)\end{array}$ & & $\begin{array}{c}0.01 \\
(0.02)\end{array}$ \\
\hline Indicator of central city tract, 1990 & & $\begin{array}{c}-0.10^{* * * *} \\
(0.03)\end{array}$ & & $\begin{array}{c}-0.12 * * * \\
(0.03)\end{array}$ \\
\hline Percentage 1-4 unit structures, 1990 & & $\begin{array}{l}-0.03 \\
(0.02)\end{array}$ & & $\begin{array}{l}-0.03 \\
(0.02)\end{array}$ \\
\hline Percentage single family homes, 1990 & & $\begin{array}{c}-0.13 * * * \\
(0.02)\end{array}$ & & $\begin{array}{c}-0.14 * * * \\
(0.02)\end{array}$ \\
\hline Number of owner occupied units, 1990 & & $\begin{array}{c}0.01 \\
(0.01)\end{array}$ & & $\begin{array}{c}0.01 \\
(0.01)\end{array}$ \\
\hline Change in the number of units, $1990 \mathrm{~s}$ & & $\begin{array}{l}0.04 * * \\
(0.01)\end{array}$ & & $\begin{array}{l}0.04 * * \\
(0.01)\end{array}$ \\
\hline Change in median family income, $1990 \mathrm{~s}$ & & $\begin{array}{l}-0.01 \\
(0.01)\end{array}$ & & $\begin{array}{l}-0.01 \\
(0.01)\end{array}$ \\
\hline Homeownership rate, 1990 & & $\begin{array}{l}0.09 * * \\
(0.03)\end{array}$ & & $\begin{array}{c}0.11 * * * \\
(0.03)\end{array}$ \\
\hline Vacancy rate, 1990 & & $\begin{array}{c}0.00 \\
(0.01)\end{array}$ & & $\begin{array}{c}0.01 \\
(0.02)\end{array}$ \\
\hline Median house value, 1990 & & $\begin{array}{c}-0.09 * * * \\
(0.02)\end{array}$ & & $\begin{array}{c}-0.10 * * * \\
(0.03)\end{array}$ \\
\hline
\end{tabular}


Table 4 (continued): Regression results for percent change of FHA market share, 1996-2000

\begin{tabular}{|c|c|c|c|c|}
\hline & \multicolumn{2}{|c|}{ All loans } & \multicolumn{2}{|c|}{ FHA-eligible loans } \\
\hline & Model 1 & Model 2 & Model 3 & Model 4 \\
\hline Per capita income in PMSA, 1990 & & $\begin{array}{c}-0.08 * * * \\
(0.02)\end{array}$ & & $\begin{array}{c}-0.10 * * * \\
(0.02)\end{array}$ \\
\hline Share of population employed in PMSA, 1990 (\%) & & $\begin{array}{c}0.01 \\
(0.02)\end{array}$ & & $\begin{array}{c}0.02 \\
(0.02)\end{array}$ \\
\hline Change in PMSA per capita income, 1990s & & $\begin{array}{c}-0.05^{* *} \\
(0.02)\end{array}$ & & $\begin{array}{c}-0.05^{* *} \\
(0.02)\end{array}$ \\
\hline Change in PMSA employment, 1990s & & $\begin{array}{c}0.07 * * * \\
(0.02)\end{array}$ & & $\begin{array}{c}0.08 * * * \\
(0.02)\end{array}$ \\
\hline $\begin{array}{l}N \\
\text { Adjusted R-square }\end{array}$ & $\begin{array}{c}6,821 \\
0.0347\end{array}$ & $\begin{array}{c}6,821 \\
0.0898\end{array}$ & $\begin{array}{c}6,640 \\
0.0133\end{array}$ & $\begin{array}{c}6,640 \\
0.0836\end{array}$ \\
\hline
\end{tabular}

NOTE: Standard errors are in parenthesis, ${ }^{* * *}-\mathrm{p}<.001,{ }^{* *}-\mathrm{p}<.01$, and ${ }^{*}-\mathrm{p}<.05$. GSE and FHA market share are defined as percentage of loans purchases by GSEs or insured by FHA of the total origination in each census tract in one specific year. Only tracts with 80 to 100 percent of MSA median family income are included, among which tracts with 80 to 90 percent of MSA median family income are GSE targets. All change variables are in percent and all continuous variables are standardized before running the regression. 
Table 5: Regression results for examination of whether the "FHA feedback effect" varies with respect to affordability, 1996-2000

\begin{tabular}{|c|c|c|}
\hline & All loans & $\begin{array}{c}\text { FHA-eligible } \\
\text { loans }\end{array}$ \\
\hline Intercept & $\begin{array}{l}0.04 * \\
(0.02)\end{array}$ & $\begin{array}{l}0.05 * * \\
(0.02)\end{array}$ \\
\hline Percent change in GSE market share & $\begin{array}{c}-0.10 * * * \\
(0.01)\end{array}$ & $\begin{array}{c}-0.09 * * * \\
(0.01)\end{array}$ \\
\hline Low affordable area*Percent change in GSE market share & $\begin{array}{l}-0.01 \\
(0.01)\end{array}$ & $\begin{array}{l}-0.01 \\
(0.01)\end{array}$ \\
\hline Percent change in proportion of FHA eligible loans & $\begin{array}{c}0.05^{* * *} \\
(0.01)\end{array}$ & \\
\hline Percent change in total number of loan originations & $\begin{array}{c}0.15^{* * *} \\
(0.01)\end{array}$ & \\
\hline Percent change in number FHA-eligible loans & & $\begin{array}{l}-0.02 \\
(0.02)\end{array}$ \\
\hline Percent change in average loan to income ratio & $\begin{array}{c}-0.14 * * * \\
(0.02)\end{array}$ & $\begin{array}{c}0.11 * * * \\
(0.01)\end{array}$ \\
\hline Percentage aged 17 or less, 1990 & $\begin{array}{l}0.04^{*} \\
(0.02)\end{array}$ & $\begin{array}{l}0.04^{*} \\
(0.02)\end{array}$ \\
\hline Percentage aged 65 or older, 1990 & $\begin{array}{c}0.07 * * * \\
(0.02)\end{array}$ & $\begin{array}{c}0.07 * * * \\
(0.02)\end{array}$ \\
\hline Percentage minority, 1990 & $\begin{array}{l}-0.03 \\
(0.02)\end{array}$ & $\begin{array}{l}-0.03 \\
(0.02)\end{array}$ \\
\hline Percentage Asian, 1990 & $\begin{array}{c}0.01 \\
(0.02)\end{array}$ & $\begin{array}{c}0.02 \\
(0.02)\end{array}$ \\
\hline Unemployment rate, $1990(\%)$ & $\begin{array}{c}0.08^{* * * *} \\
(0.01)\end{array}$ & $\begin{array}{c}0.07 * * * \\
(0.01)\end{array}$ \\
\hline Household size, 1990 & $\begin{array}{c}0.02 \\
(0.02)\end{array}$ & $\begin{array}{c}0.02 \\
(0.02)\end{array}$ \\
\hline Indicator of central city tract, 1990 & $\begin{array}{c}-0.10 * * * \\
(0.03)\end{array}$ & $\begin{array}{c}-0.10^{* * * *} \\
(0.03)\end{array}$ \\
\hline Percentage 1-4 unit structures, 1990 & $\begin{array}{l}-0.03 \\
(0.02)\end{array}$ & $\begin{array}{l}-0.04 \\
(0.02)\end{array}$ \\
\hline Percentage single family homes, 1990 & $\begin{array}{c}-0.13 * * * \\
(0.02)\end{array}$ & $\begin{array}{c}-0.13 * * * \\
(0.02)\end{array}$ \\
\hline Number of owner occupied units, 1990 & $\begin{array}{c}0.01 \\
(0.01)\end{array}$ & $\begin{array}{c}0.00 \\
(0.01)\end{array}$ \\
\hline Change in the number of units, $1990 \mathrm{~s}$ & $\begin{array}{l}0.04 * * \\
(0.01)\end{array}$ & $\begin{array}{l}0.04 * * \\
(0.01)\end{array}$ \\
\hline Change in median family income, $1990 \mathrm{~s}$ & $\begin{array}{l}-0.01 \\
(0.01)\end{array}$ & $\begin{array}{c}0.00 \\
(0.01)\end{array}$ \\
\hline Homeownership rate, 1990 & $\begin{array}{l}0.09^{* *} \\
(0.03)\end{array}$ & $\begin{array}{l}0.09 * * \\
(0.03)\end{array}$ \\
\hline Vacancy rate, 1990 & $\begin{array}{c}0.00 \\
(0.01)\end{array}$ & $\begin{array}{l}-0.01 \\
(0.02)\end{array}$ \\
\hline Median house value, 1990 & $\begin{array}{c}-0.09 * * * \\
(0.02)\end{array}$ & $\begin{array}{c}-0.08 * * \\
(0.02)\end{array}$ \\
\hline
\end{tabular}


Table 5 (continued): Regression results for examination of whether the "FHA feedback effect” varies with respect to affordability, 1996-2000

\begin{tabular}{lcc}
\hline \hline & All loans & $\begin{array}{c}\text { FHA-eligible } \\
\text { loans }\end{array}$ \\
\hline Per capita income in PMSA, 1990 & $-0.08^{* * *}$ & $-0.11^{* * *}$ \\
Share of population employed in PMSA, 1990 (\%) & $(0.02)$ & $(0.02)$ \\
Change in PMSA per capita income, 1990s & 0.01 & 0.03 \\
& $(0.02)$ & $(0.02)$ \\
Change in PMSA employment, 1990s & $-0.05^{* *}$ & $-0.06^{* * *}$ \\
& $(0.02)$ & $(0.02)$ \\
$N$ & $0.07^{* * *}$ & $0.09^{* * *}$ \\
Adjusted R-square & $(0.02)$ & $(0.02)$ \\
\hline
\end{tabular}

NOTE: Standard errors are in parenthesis, ${ }^{* * *}-\mathrm{p}<.001, * *-\mathrm{p}<.01$, and ${ }^{*}-\mathrm{p}<.05$. GSE and FHA market share are defined as percentage of loans purchases by GSEs or insured by FHA of the total origination in each census tract in one specific year. Low affordable area is a dummy variable indicating that the tract is in an MSA which has housing cost (measured as MSA median house value divided by MSA median family income) in the upper quartile of all US MSAs. Only tracts with 80 to 100 percent of MSA median family income are included, among which tracts with 80 to 90 percent of MSA median family income are GSE targets. All change variables are in percent and all continuous variables are standardized before running the regression. 


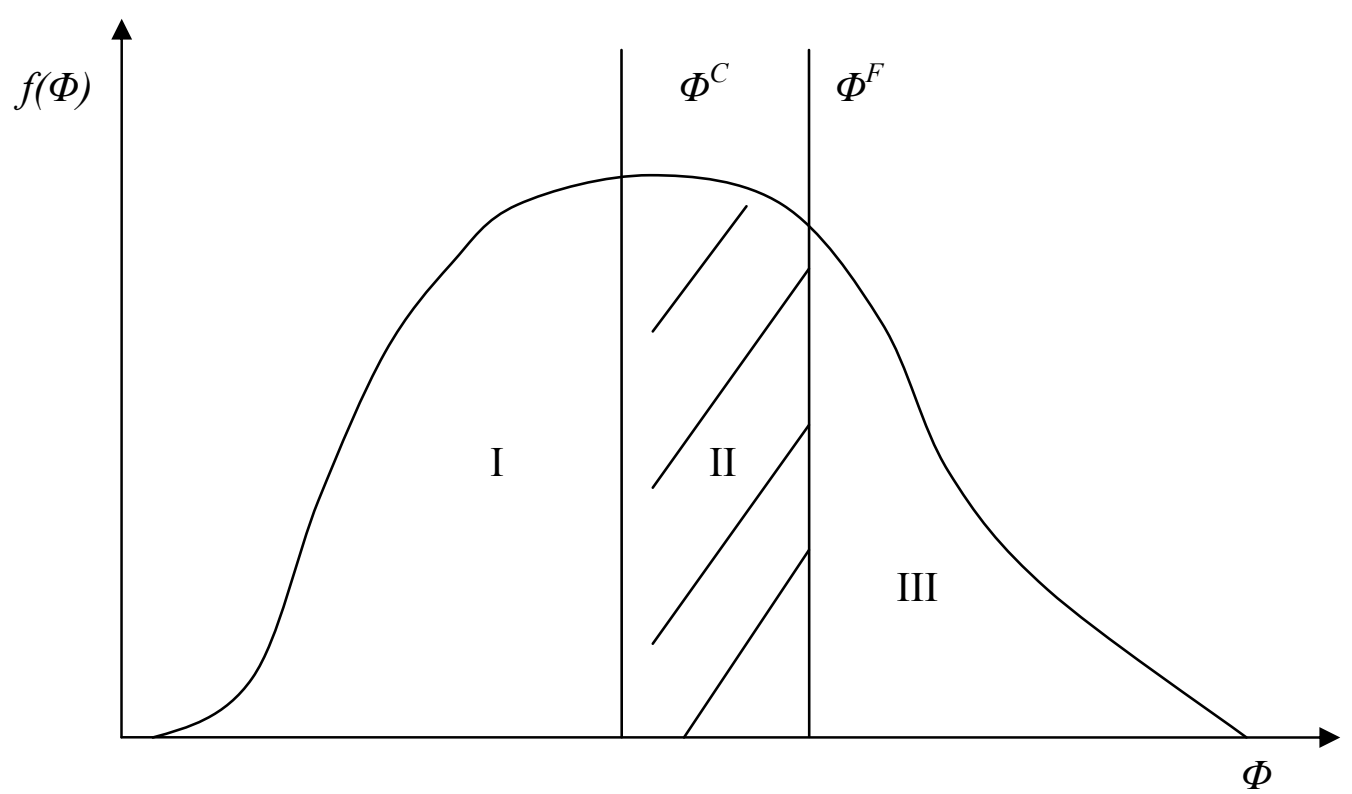

Figure 1: Market composition of conventional and FHA lending at $t_{1}$

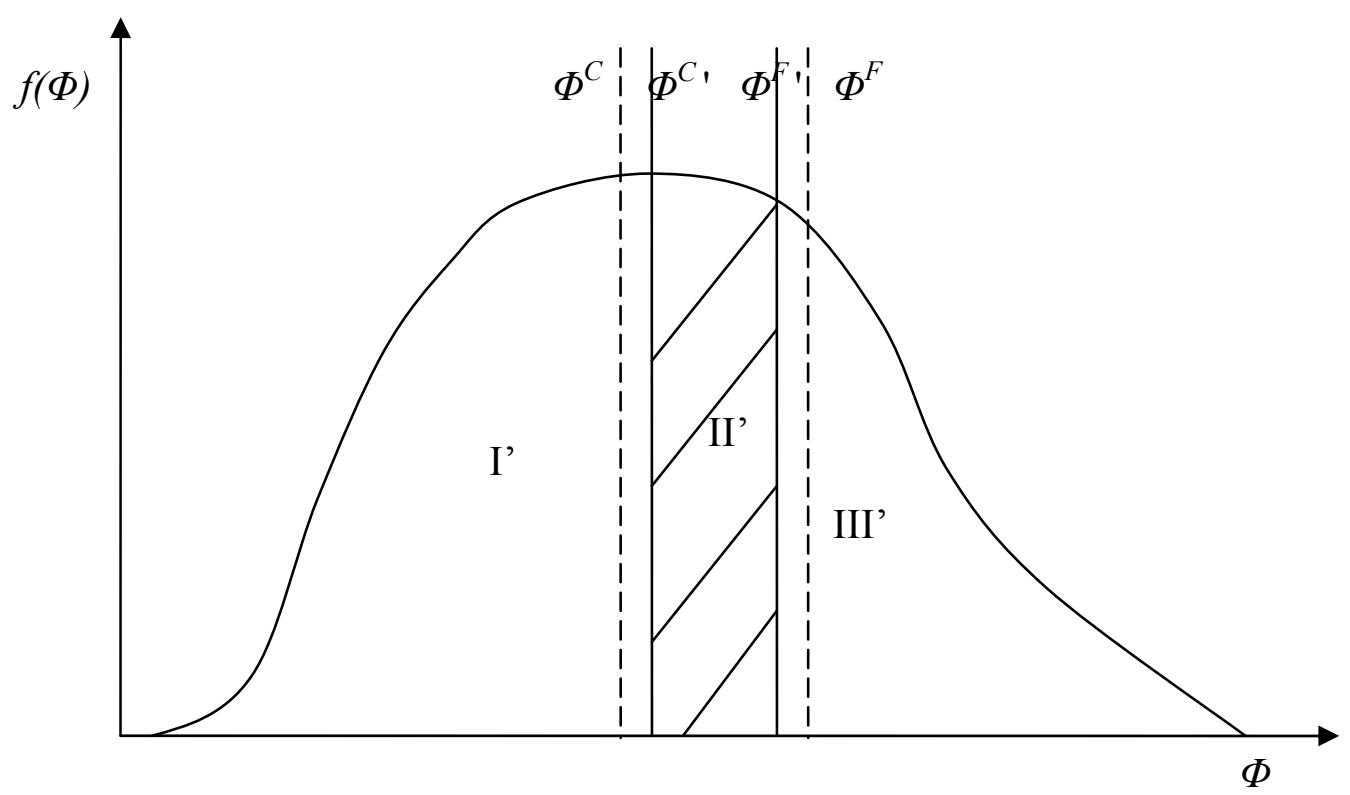

Figure 2: FHA reaction and new market composition of conventional and FHA lending at $t_{2}$ 


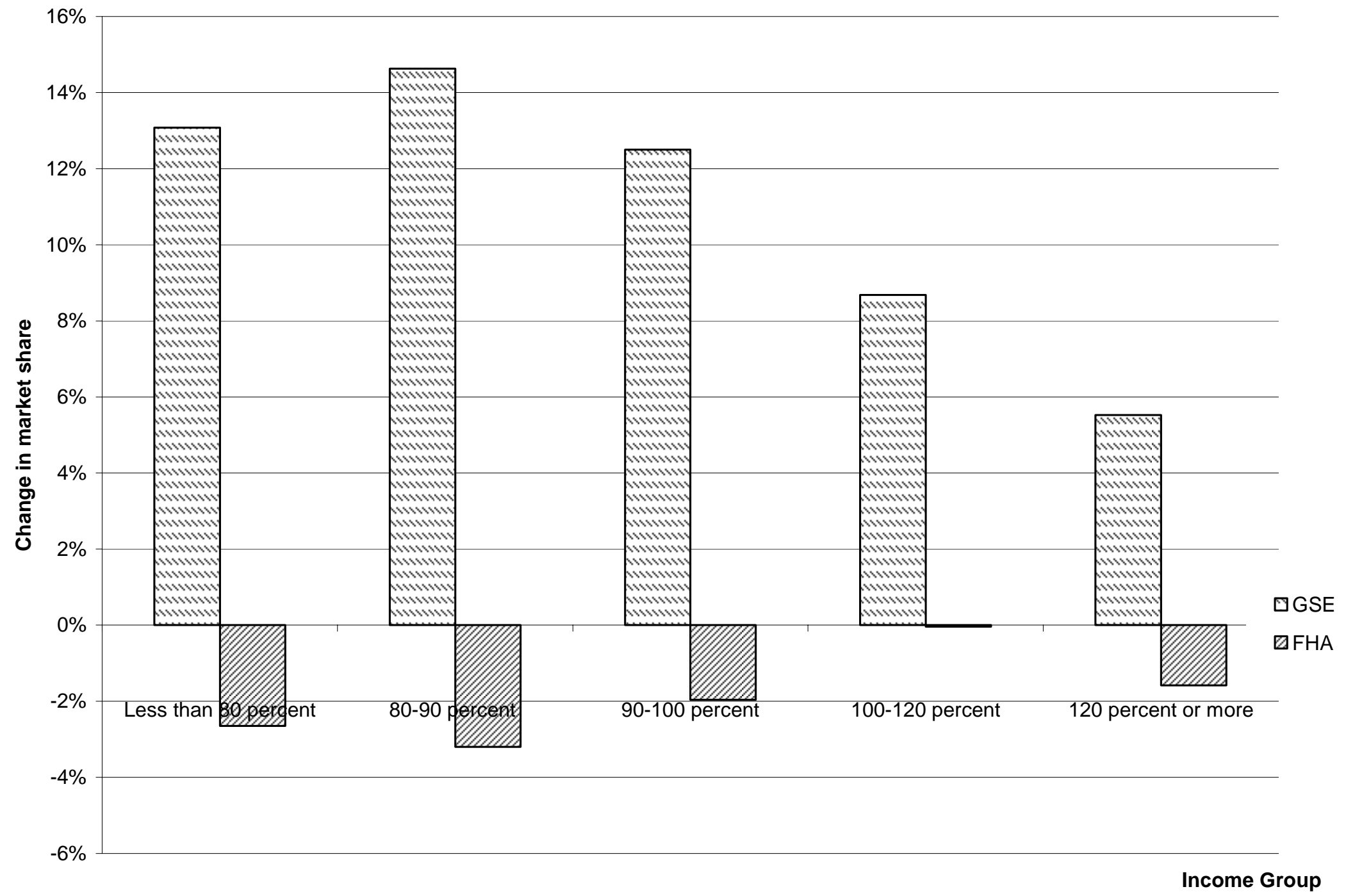

Figure 3: Changes in GSE and FHA market shares in census tracts grouped by relative income, 1996-2000 


\section{Appendix A: The HUD-specified Affordable Housing Goal Percentage Thresholds}

\begin{tabular}{lccc}
\hline \hline & \multicolumn{3}{c}{ Goal } \\
\cline { 2 - 4 } Period & $\begin{array}{c}\text { Low- and Moderate- } \\
\text { Income }\end{array}$ & $\begin{array}{c}\text { Underserved } \\
\text { Neighborhoods }\end{array}$ & Special Affordable \\
\hline $1994-1995$ & 30 & $30^{*}$ & In dollar amount \\
1996 & 40 & 21 & 12 \\
$1997-2000$ & 42 & 24 & 14 \\
$2001-2004$ & 50 & 31 & 20 \\
$2005-2008$ & $52-56$ & $37-39$ & $22-27$ \\
\hline
\end{tabular}

NOTE: All figures are percentages of the total number of units covered by the mortgages purchased by each GSE. The year 1994 and 1995 is the experimental period, with the underserved neighborhoods defined differently from the current definition. The thresholds for 1996-2000 were published on December 1, 1995, those for 2001-2003 were published on October 31,2000 , and those for 2005-2008 were published on November 2, 2004. HUD explains that is increase of the underserved neighborhoods goal from $31 \%$ to $37 \%$ incorporates the effects of 2000 census data, under which the 2001-2004 31\% goal would be $36 \%$. 


\section{Appendix B: The Interest Rate Environment for the Study Period}

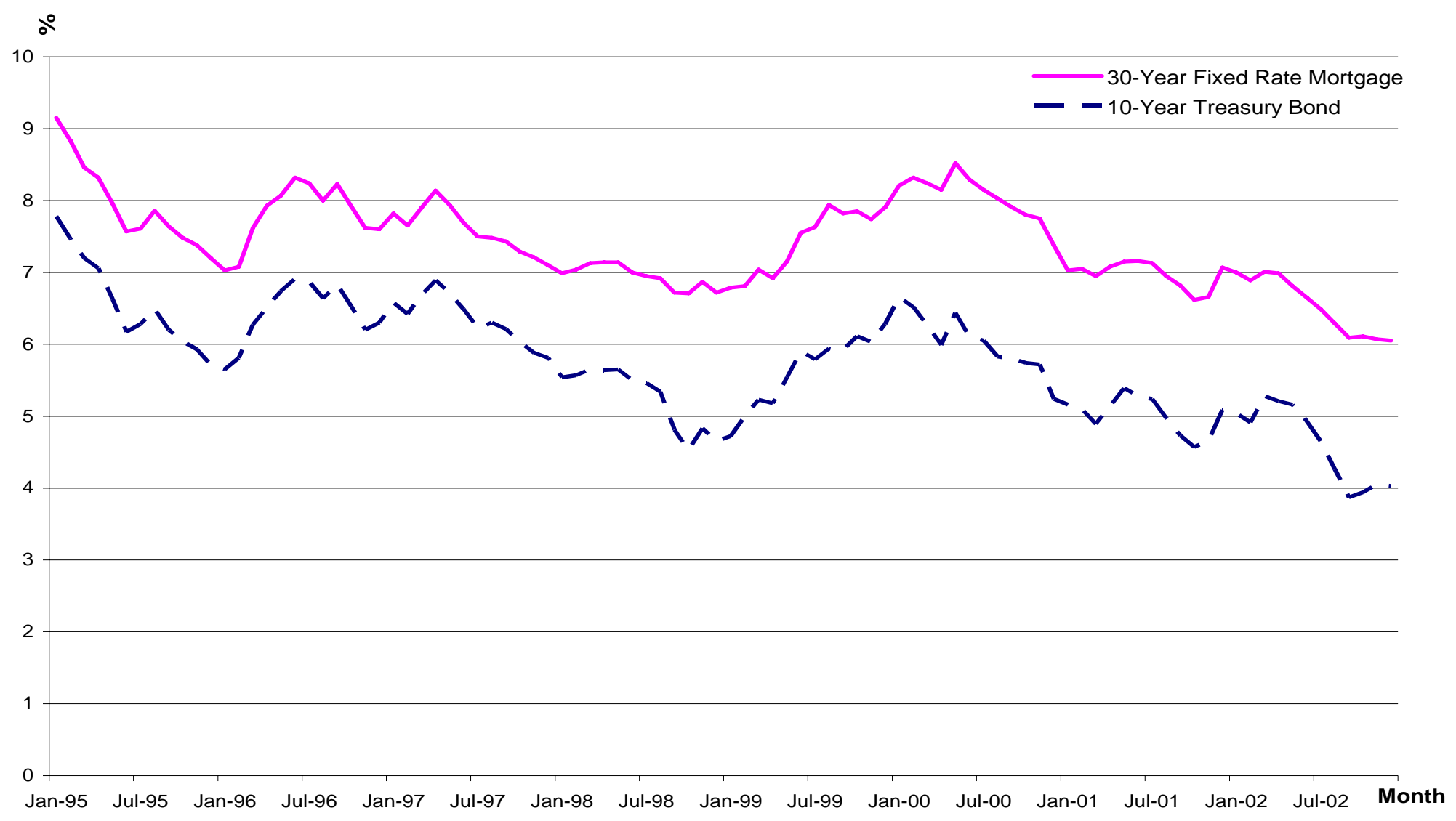

